\title{
Intravascular Large B-Cell Lymphoma Diagnosed on Prostate Biopsy: A Case Report
}

\section{Prostat Biopsisinde Tanı Konulan İntravasküler Büyük B Hücreli Lenfoma: Olgu Sunumu}

\author{
Nazan Özsan1, Banu Sarsık1, Asu Fergün Yılmaz², Adnan Şimşir ${ }^{3}$, Ayhan Dönmez² \\ ${ }^{1}$ Ege University Faculty of Medicine, Department of Pathology, İzmir, Turkey \\ ${ }^{2}$ Ege University Faculty of Medicine, Department of Hematology, İzmir, Turkey \\ ${ }^{3}$ Ege University Faculty of Medicine, Department of Urology, İzmir, Turkey
}

\begin{abstract}
:
Intravascular large B-cell lymphoma (IVLBCL) is a very rare type of non-Hodgkin lymphoma, usually affecting elderly patients and characterized by selective infiltration of neoplastic cells within blood vessels' lumina. IVLBCL diagnosed with prostatic involvement is extremely rare. We report a patient of 65 years old, having mostly neurological complaints but diagnosed with IVLBCL upon histopathological examination of transurethral prostate resection material, which revealed large neoplastic cell infiltration totally limited within the lumens of small vessels. By immunohistochemistry, neoplastic cell infiltration was positive with MUM1, bcl-6, and bcl-2 and negative with ALK1, CD10, and CD30, with a high Ki-67 proliferation index. CD34 and CD31 staining showed expression in endothelial cells, highlighting the intravascular nature of neoplastic infiltrate. The patient unfortunately refused to receive treatment and died of the disease 8 months after the diagnosis. IVLBCL, though very rare, should be considered in differential diagnosis of all organ biopsies with intravascular infiltration. Further improvements in the understanding of the pathogenesis and biology of this rare type of lymphoma are mandatory.
\end{abstract}

Key Words: Non-Hodgkin lymphoma, Intravascular large B-cell lymphoma, Prostate, Non-germinal center B-cell

Özet:

İntravasküler büyük B hücreli lenfoma (IVBBHL), non-Hodgkin lenfomaların nadir bir tipidir, genellikle ileri yaşta görülür, ve neoplastik hücrelerin damar lümeni içerisinde seçici infiltrasyonu ile karakterlidir. Prostat tutulumu ile tanı konan IVBBHL olguları ise çok nadirdir. Altmış beş yaşında, daha çok nörolojik şikayetleri olan, ancak transüretral prostat rezeksiyon materyalinin histopatolojik incelemesinde, tamamen küçük damar lümenleri içerisinde sınırlı neoplastik büyük hücre infiltrasyonunun görülmesi ile tanı konan bir olguyu sunuyoruz. Neoplastik hücre infiltrasyonu immunhistokimyasal incelemede MUM1, bcl-6 ve bcl-2 ile pozitif, ALK1, CD10, CD30 ile negatif saptandı, Ki67 proliferasyon indeksi yüksekti. CD34 ve CD31 endotelial hücrelerde pozitif olup, neoplastik infiltrasyonun damar içi yerleşimini belirgin olarak ortaya koydu. Hasta, ne yazık ki tedavi almayı kabul etmedi ve sekiz ay içerisinde hastalık nedeniyle kaybedildi. IVLBCL, az görülmekle birlikte, intravasküler infiltrasyon içeren tüm organ biopsilerinde ayırıcı tanı içerisinde yer almalıdır. Bu nadir lenfoma tipinin patogenez ve biyolojisinin aydınlatılmasına ihtiyaç duyulmaktadır.

Anahtar Sözcükler: Non-Hodgkin lymphoma, İntravasküler büyük B hücreli lenfoma, Prostat, Non-germinal merkez B hücre

Address for Correspondence: Nazan ÖZSAN, M.D.,

Ege University Faculty of Medicine, Department of Pathology, İzmir, Turkey

Phone: +90232 3881025 E-mail: nazanozsan@yahoo.com 


\section{Introduction}

Intravascular large B-cell lymphoma (IVLBCL) is a very rare type of non-Hodgkin lymphoma and is characterized by selective infiltration of neoplastic cells within blood vessels' lumina. IVLBCL is an aggressive disease, usually affecting elderly patients with a poor prognosis [1].

Prostatic involvement in IVLBCL is extremely rare and has been described in only a few case reports. We hereby report a 65-year-old male patient who presented with neurological symptoms and was diagnosed with IVLBCL based on transurethral prostate resection (p-TUR) material.

\section{Case Presentation}

A 65-year-old man was admitted to the hospital with complaints of cervical and back pain. His past history revealed no remarkable illnesses, and he had no evidence of human immunodeficiency virus infection or other causes of immunodeficiency.

Cervical spine magnetic resonance (MR) imaging showed signs consistent with degenerative discopathies at multiple levels and an increase in signals at the level of the conus medullaris, consistent with myelitis. Informed consent was obtained.

The patient also had complaints indicating lower urinary tract symptoms, such as difficulty in urinating.

Laboratory findings showed an increase in lactate dehydrogenase (LDH) levels (682 U/L; reference scale: 240$480 \mathrm{U} / \mathrm{L})$ and a mild decrease in platelet count $(83,000 / \mu \mathrm{L}$; reference range: $150,000-450,000 / \mu \mathrm{L})$. The prostate-specific antigen (PSA) level was in normal limits (PSA: $2.37 \mathrm{ng} / \mathrm{mL}$; reference range: $<4 \mathrm{ng} / \mathrm{mL}$; free PSA: $0.374 \mathrm{ng} / \mathrm{mL}$; F.PSA/T. PSA: 0.16 ; reference: $>0.15)$. Ultrasonography revealed enlargement in prostatic dimensions of $41 \times 40 \times 36 \mathrm{~mm}$ in size. p-TUR with spinal anesthesia was performed. After the surgery, the patient developed paraplegia and urinary and fecal incontinence. Lumbar spine MR imaging done after the surgery revealed signs consistent with lumbar spondylolysis, degenerative changes at multiple levels, and an increase of signals in the conus medullaris, which may reveal myelitis. He was then given prednisolone at $1 \mathrm{~g}$ /day for 10 days with the diagnosis of myelitis upon neurology consultation.

Histopathological examination of the p-TUR specimen revealed large neoplastic cell infiltration totally limited within the lumens of small vessels in the stroma, while acinar and glandular structures were all benign.

Immunohistochemical analysis was performed on paraffin-embedded tissue sections with an automated stainer (Ventana Benchmark XT, Ventana Medical Systems, Tucson, AZ, USA) according to protocol. A streptavidin-biotin- peroxidase detection system with diaminobenzidine as a chromogen was used to visualize bound secondary antibodies. The intravascular neoplastic cells were positive for CD20 and negative for CD3 and pan-cytokeratin. The following panel of antibody testing was then performed: CD10, bcl- 6 , bcl2, IRF4/MUM1, CD30, Ki-67, CD34, ALK, and CD31. The antibodies were scored as positive when $>30 \%$ of tumor cells showed immunoexpression. Neoplastic cell infiltration was positive with MUM1, bcl-6, and bcl-2 and negative with ALK1, CD10, and CD30. The Ki-67 proliferation index was high, showing expression in about $90 \%$ of neoplastic large cells. CD34 and CD31 stainings showed expression in endothelial cells, highlighting the intravascular nature of the neoplastic infiltrate. In situ hybridization analysis was also performed using oligonucleotides complementary to Epstein-Barr early RNA transcripts in tissue sections of paraffin-embedded tissue in the same automated stainer (Ventana Medical Systems), which revealed negative results. The immunohistochemical expressions (IRF4/MUM1 and bcl-6 positivity, with CD10 negativity) revealed a non-germinal center B cell (non-GCB) phenotype when classified according to the Hans criteria [2]. The patient was diagnosed with IVLBCL from the p-TUR material.

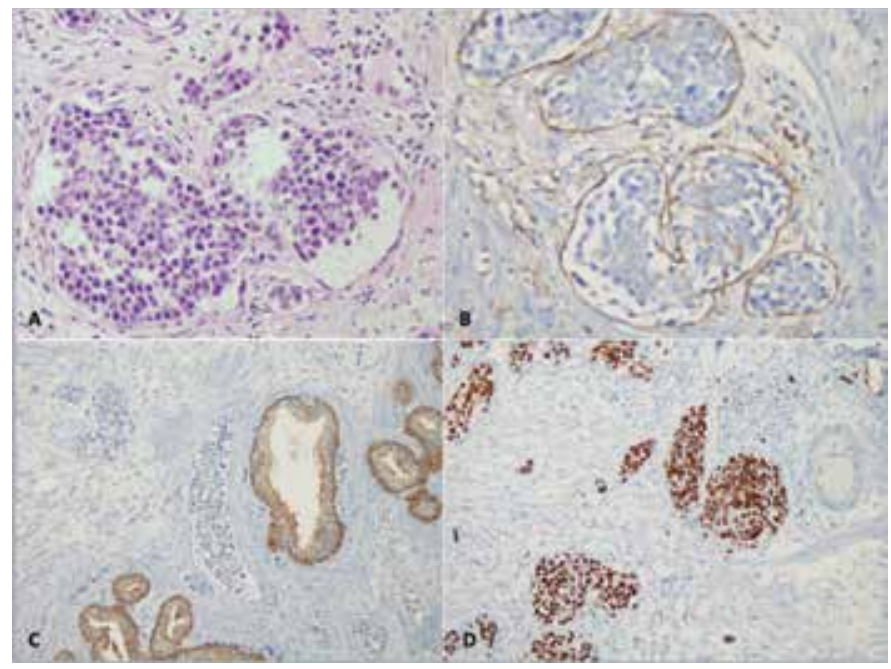

Figure 1. A) Infiltration of neoplastic large cells in the lumen of small vessels in transurethral prostate resection material (hematoxylin and eosin, original magnification: x200) by immunohistochemistry; B) CD31 staining with expression in endothelial cells highlighted the intravascular nature of neoplastic infiltrate (immunoperoxidase, original magnification: $\mathrm{x} 400)$; C) Neoplastic infiltration is negative with cytokeratine, while benign glandular structures are positive (immunoperoxidase, original magnification: x200); D) Ki67 staining showed a high proliferation index in neoplastic cells (immunoperoxidase, original magnification: x200). 
The patient was hospitalized in the hematology department with a diagnosis of lymphoma. No enlarged superficial lymph nodes were found on physical examination. Positron emission tomography-computed tomography (PET-CT) showed an increase in fluorodeoxyglucose signals in both kidneys, which was interpreted as consistent with an inflammatory origin. Upper abdominal ultrasonography revealed mild splenomegaly (135 $\mathrm{mm}$ ). The patient was given prednisolone at $1 \mathrm{~g}$ /day for 10 days, when bone marrow biopsy was performed. Bone marrow biopsy revealed no infiltration of lymphoma from either morphology or immunohistochemistry. R-CHOP chemotherapy was planned, but the patient refused to receive therapy and was discharged at his request. He received no therapy for IVLBCL and died from the disease 8 months after the diagnosis.

\section{Discussion and Review of the Literature}

In the current World Health Organization classification of hematopoietic neoplasms, IVLBCL is defined as a rare type of extranodal large B-cell lymphoma characterized by the selective infiltration of neoplastic cells in the lumina of vessels and capillaries, with the exception of large arteries and veins [3]. The disease is widely disseminated in extranodal sites: the bone marrow, central nervous system, skin, lungs, liver, and spleen are the most common sites of involvement [4]. Lymph node infiltration and lymphadenopathy are usually absent [5]. The clinical signs and symptoms are variable, related to the site of involvement. Neoplastic cells are rarely seen in bone marrow and peripheral blood smears and so IVLBCL is very difficult to diagnose; most of the cases reported have been confirmed by autopsy or cutaneous biopsies [6]. IVLBCL diagnosed in prostate specimens is extremely rare

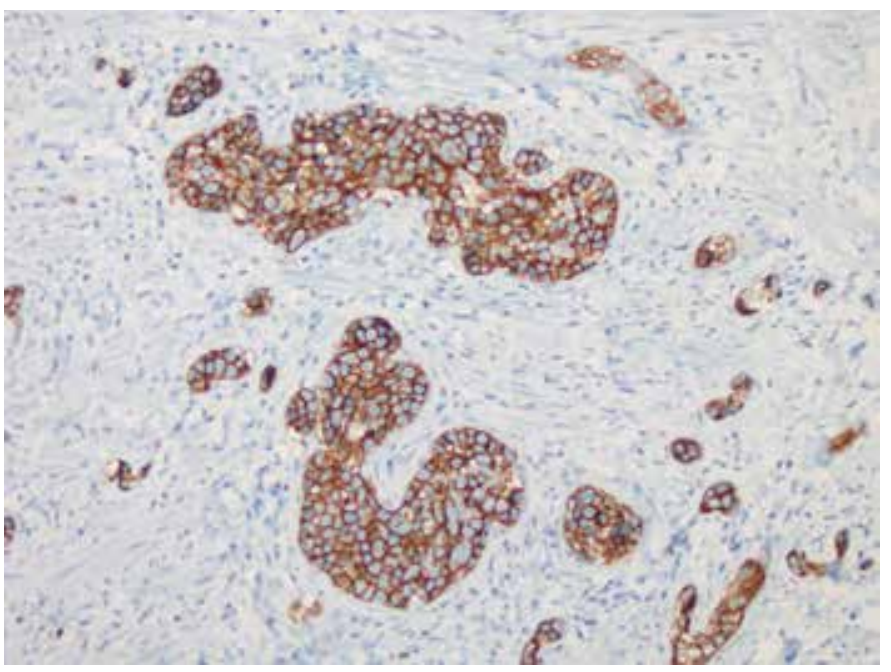

Figure 2. Neoplastic large cells filling the vessels are strongly positive with CD20 (immunoperoxidase, original magnification: $\mathrm{x} 200$ ). in the literature, usually reported as single cases; to the best of our knowledge, this is the 10th such case reported $[1,7,8,9,10,11,12]$. Furthermore, none of the patients in the study by Murase et al., with a large series of 96 patients, were diagnosed with prostatic involvement, indicating the rarity of infiltration in this site [6].

All reported cases of primary IVLBCL of the prostate are in elderly patients aged above 60 years [10], and the median age defined for all IVLBCL cases is 67 years (range: $13-85$ years) [4].

There are no specific laboratory findings indicating IVLBCL, but most patients were reported to display few pathologic findings in their complete blood counts, which should raise suspicion. Ferreri et al., in the study of a series of 38 patients, reported anemia in nearly $65 \%$ of patients, increased LDH and $\beta 2$ microglobulin levels in more than $80 \%$ of patients, and an elevated sedimentation component in $14 \%$ of patients [1]. Our patient had an increased LDH level and mild thrombocytopenia. He had complaints indicating lower urinary tract symptoms, which led to a urinary tract examination. No increase in PSA levels was found, but ultrasonography revealed enlargement in prostatic dimensions, leading to p-TUR surgery. The diagnosis of IVLBCL was established based on histopathological and immunohistochemical assessment of the biopsy. Neoplastic cell infiltration was totally limited within the lumens of small vessels in the stroma, within benign acinar and glandular structures. Neoplastic cell infiltration was positive with CD20, MUM1, bcl-6, and bcl-2 and negative with ALK1, CD10, CD30, and cytokeratin, with a high Ki-67 proliferation index. CD34 and CD31 staining with expression in endothelial cells highlighted the intravascular nature of the neoplastic infiltrate (Figures 1 and 2). The immunohistochemical profile of infiltration revealed a non-GCB cell phenotype (negative for CD10 and positive for IRF4/MUM1 and bcl-6) when classified according to the Hans criteria. Kanda et al. suggested that most IVLBCL cases might originate from post-germinal center cells, based on the presence of somatic mutation in variable regions of immunoglobulin heavy chain genes [13]. Subsequent studies supported their assertion as most IVLBCL cases have been reported to be of non-GCB cell origin $[5,6]$.

Our patient had no enlarged lymph nodes; bone marrow biopsy showed no infiltration of lymphoma. Upper abdominal ultrasonography revealed mild splenomegaly, but PET-CT showed no findings consistent with extra sites of infiltration; according to these findings, he had stage $1 \mathrm{E}$ disease. In a study of 38 intravascular lymphoma patients, Ferreri et al. reported that $40 \%$ of the patients diagnosed in vivo had stage 1E disease according to the Ann Arbor staging system, but a disseminated infiltration was shown by autopsy in some stage I disease patients when death occurred a short time after diagnosis, highlighting the limitations of staging procedures 
in intravascular lymphoma patients [1,14]. The relatively high proportion of false negativity in classical staging procedures can be attributed to the fact that IVLBCL infiltration may usually be seen without tumor masses and apparent signs of involvement or lymphadenopathy [15].

The clinical manifestations of IVLBCL are extremely variable and symptoms are mostly related to the involved organ. Interestingly, clinical manifestations of the disease have been shown to differ between 2 distinct geographical areas. In Asian countries, hemophagocytic syndrome, bone marrow involvement, hepatosplenomegaly, fever, and thrombocytopenia have been documented at high frequencies, while central nervous system and skin involvements are predominantly seen in European countries [1,16]. Despite the defined geographical differences, neurological symptoms at initial diagnosis were reported in high incidences in both the Asian and Western types of the disease at 25\% and 36\%, respectively [1,17]. Among the few cases reported with prostatic involvement, 2 patients presented with neurological signs indicating spinal cord lesions [8,9]. Our patient had some neurological symptoms interpreted as myelitis according to MR findings, and following p-TUR surgery with spinal anesthesia, paraparesis developed. Whether these neurological symptoms were due to real neurological pathologies or to the invasion of tumor cells into the central nervous system or peripheral nerves remains unclear because an autopsy was not performed.

The disease has an aggressive behavior, usually with a short outcome and fatal course [1]. The use of rituximab-containing chemotherapy regimens for the treatment of IVLBCL has been reported to improve outcomes $[17,18]$.

Ferreri et al. reported overall survival at 3 years as $81 \%$ in 33 patients receiving immunochemotherapy [18]. Highdose chemotherapy with the support of autologous stem cell transplantation was shown to have efficacy in several reports $[19,20]$. Despite all treatment modalities, our patient refused to receive treatment for lymphoma and unfortunately died of the disease 8 months after the diagnosis.

IVLBCL, though very rare, should be considered in differential diagnosis for elderly patients with elevated LDH levels, fever of unknown origin, and unexplained neurological symptoms. As for prostatic involvement, lower urinary tract obstruction symptoms can be seen, but an elevated level of PSA is not a common finding for lymphoma infiltration in the prostate, including rare IVLBCL cases [21]. Biopsy and immunohistochemical assessment are required for the diagnosis. Early diagnosis can result in a better outcome with the recent treatment options. Further improvements in the understanding of the pathogenesis and biology of this rare type of lymphoma are mandatory to achieve better outcomes for IVLBCL patients.

\section{Conflict of Interest Statement}

The authors of this paper have no conflicts of interest, including specific financial interests, relationships, and/or affiliations relevant to the subject matter or materials included.

\section{References}

1. Ferreri AJ, Campo E, Seymour JF, Willemze R, Ilariucci F, Ambrosetti A, Zucca E, Rossi G, López-Guillermo A, Pavlovsky MA, Geerts ML, Candoni A, Lestani M, Asioli S, Milani M, Piris MA, Pileri S, Facchetti F, Cavalli F, Ponzoni M. International Extranodal Lymphoma Study Group (IELSG). Intravascular lymphoma: clinical presentation, natural history, management and prognostic factors in a series of 38 cases, with special emphasis on the 'cutaneous variant'. Br J Haematol 2004;127:173-183.

2. Hans CP, Weisenburger DD, Greiner TC, Gascoyne RD, Delabie J, Ott G, Müller-Hermelink HK, Campo E, Braziel RM, Jaffe ES, Pan Z, Farinha P, Smith LM, Falini B, Banham AH, Rosenwald A, Staudt LM, Connors JM, Armitage JO, Chan WC. Confirmation of the molecular classification of diffuse large B-cell lymphoma by immunohistochemistry using a tissue microarray. Blood 2004;103:275-282.

3. Nakamura S, Ponzoni M, Campo E. Intravascular large B-cell lymphoma. In: Swerdlow SH, Campo E, Harris NL, Jaffe ES, Pileri SA, Stein H, Thiele J, Vardiman JW (eds). WHO Classification of Tumours of Haematopoietic and Lymphoid Tissues. Lyon, France, IARC, 2008.

4. Ferreri AJ, Dognini GP, Campo E, Willemze R, Seymour JF, Bairey O, Martelli M, De Renz AO, Doglioni C, Montalbán C, Tedeschi A, Pavlovsky A, Morgan S, Uziel L, Ferracci M, Ascani S, Gianelli U, Patriarca C, Facchetti F, Dalla Libera A, Pertoldi B, Horváth B, Szomor A, Zucca E, Cavalli F, Ponzoni M. Variations in clinical presentation, frequency of hemophagocytosis and clinical behavior of intravascular lymphoma diagnosed in different geographical regions. Haematologica 2007;92:486-492.

5. Shimada K, Kinoshita T, Naoe T, Nakamura S. Presentation and management of intravascular large B-cell lymphoma. Lancet Oncol 2009; 10:895-902.

6. Murase T, Yamaguchi M, Suzuki R, Okamoto M, Sato Y, Tamaru J, Kojima M, Miura I, Mori N, Yoshino T, Nakamura S. Intravascular large B-cell lymphoma (IVLBCL): a clinicopathologic study of 96 cases with special reference to the immunophenotypic heterogeneity of CD5. Blood 2007;109:478-485.

7. Alfaro J, Espinoza A, Manciquez M, Moyano L, González N, Larrondo M, Figueroa G. Intravascular lymphoma treated with anti CD20 monoclonal antibodies. Report of one case. Rev Med Chil 2004;132:1403-1406 (article in Spanish with English abstract). 
8. Pusch G, Feher G, Szomor A, Kover F, Gomori E, Illes Z Intravascular lymphoma presenting with neurological signs but diagnosed by prostate biopsy: suspicion as a key to early diagnosis. Eur J Neurol 2009;16:39-41.

9. Quintini G, Barbera V, Franco V, Florena AM, Spadola V, Mariani G. Uncommon presentations of non-Hodgkin's lymphoma: case 1. Intravascular large B-cell lymphoma: diagnosis on prostate biopsy. J Clin Oncol 2003;21:564-565.

10. Xu M, Yang Q, Li M, Geng W, Huang W, Chen Y. Prostate involvement by intravascular large B-cell lymphoma: a case report with literature review. Int J Surg Pathol 2011;19:544547.

11. Yin XR, Liu H, Chen HQ. Intravascular lymphomatosis of the prostate gland. Zhonghua Bing Li Xue Za Zhi 2005;34:189-90 (article in Chinese).

12. Csomor J, Kaszás I, Kollár B, Pajor L, Egyházi Z, Fekete S, Egyed M, Timár B. Prolonged survival using anti-CD20 combined chemotherapy in primary prostatic intravascular large B-cell lymphoma. Pathol Oncol Res 2008;14:281-284.

13. Kanda M, Suzumiya J, Ohshima K, Haraoka S, Nakamura N, Abe M, Tamura K, Kikuchi M. Analysis of the immunoglobulin heavy chain gene variable region of intravascular large B-cell lymphoma. Virchows Arch 2001;439:540-546.

14. Ponzoni M, Ferreri AJ. Intravascular lymphoma: a neoplasm of 'homeless' lymphocytes? Hematol Oncol 2006;24:105112.

15. Ponzoni M, Ferreri AJ, Campo E, Facchetti F, Mazzucchelli L, Yoshino T, Murase T, Pileri SA, Doglioni C, Zucca E, Cavalli F, Nakamura S. Definition, diagnosis, and management of intravascular large B-cell lymphoma: proposals and perspectives from an international consensus meeting. J Clin Oncol 2007:25:3168-3173.

16. Murase T, Nakamura S, Kawauchi K, Matsuzaki H, Sakai C, Inaba T, Nasu K, Tashiro K, Suchi T, Saito H. An Asian variant of intravascular large B-cell lymphoma: clinical, pathological and cytogenetic approaches to diffuse large B-cell lymphoma associated with haemophagocytic syndrome. Br J Haematol 2000;111:826-834.
17. Shimada K, Matsue K, Yamamoto K, Murase T, Ichikawa N, Okamoto M, Niitsu N, Kosugi H, Tsukamoto N, Miwa H, Asaoku H, Kikuchi A, Matsumoto M, Saburi Y, Masaki Y, Yamaguchi M, Nakamura S, Naoe T, Kinoshita T. Retrospective analysis of intravascular large B-cell lymphoma treated with rituximab-containing chemotherapy as reported by the IVL study group in Japan. J Clin Oncol 2008;26:3189-3195.

18. Ferreri AJ, Dognini GP, Govi S, Crocchiolo R, Bouzani M, Bollinger CR, D'Incan M, Delaporte E, Hamadani M, Jardin F, Martusewicz-Boros M, Montanari M, Szomor A, Zucca E, Cavalli F, Ponzoni M. Can rituximab change the usually dismal prognosis of patients with intravascular large B-cell lymphoma? J Clin Oncol 2008;26:5134-5136; author reply 5136-5137.

19. Sawamoto A, Narimatsu H, Suzuki T, Kurahashi S, Sugimoto T, Sugiura I. Long-term remission after autologous peripheral blood stem cell transplantation for relapsed intravascular lymphoma. Bone Marrow Transplant 2006;37:233-234.

20. Bertz H, Zeiser R, Lange W, Fetscher S, Waller CF, Finke J. Longterm follow-up after high-dose chemotherapy and autologous stem-cell transplantation for high-grade B-cell lymphoma suggests an improved outcome for high-risk patients with respect to the age-adjusted International Prognostic Index. Ann Oncol 2004;15:1419-1424.

21. Kataja VV, Colleoni M, Bergh J. ESMO Minimum Clinical Recommendations for diagnosis, treatment and follow-up of locally recurrent or metastatic breast cancer (MBC). Ann Oncol 2005;16(Suppl.1):10-12. 